\title{
Impact of Digital India on Education System
}

\author{
C. K. Hebbar \\ Research Professor, College of Management \& Commerce, Srinivas University, Mangalore \\ -575001, India \\ E-mail: hebbrkc@yahoo.com
}

Area of the Paper: Business Management.

Type of the Paper: Conceptual Research.

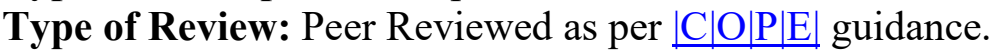

Indexed In: OpenAIRE.

DOI: http://doi.org/10.5281/zenodo.3988884.

Google Scholar Citation: IJCSBE.

\section{How to Cite this Paper:}

Hebbar, C. K. (2020). Impact of Digital India on Education System. International Journal of Case Studies in Business, IT, and Education (IJCSBE), 4(2), 65-70.

DOI: http://doi.org/10.5281/zenodo.3988884.

International Journal of Case Studies in Business, IT and Education (IJCSBE)

A Refereed International Journal of Srinivas University, India.

(C) With Author.

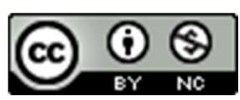

This work is licensed under a Creative Commons Attribution Non-Commercial 4.0 International License subject to proper citation to the publication source of the work.

Disclaimer: The scholarly papers as reviewed and published by the Srinivas Publications (S.P.), India are the views and opinions of their respective authors and are not the views or opinions of the S.P. The S.P. disclaims of any harm or loss caused due to the published content to any party. 


\title{
Impact of Digital India on Education System
}

\author{
C. K. Hebbar \\ Research Professor, College of Management \& Commerce, Srinivas University, Mangalore - \\ 575001, India \\ E-mail: hebbrkc@yahoo.com
}

\begin{abstract}
Digital education is a campaign initiated by the Indian Government to move towards a new direction and ensure that education services are made accessible electronically to a student through enhanced online infrastructure. This paper is focused largely on both primary and secondary data. Primary data is collected primarily from the education sector by lectures and students about how much they like emerging technologies. Since changes are happening anyway, the best thing is to know more about them, so we can lay hold of them and turn them in the direction of our wishes.
\end{abstract}

Keywords: Digitalization, Digital India, Classroom, Brahmastra.

\section{INTRODUCTION :}

The System consists of a set of rules, procedures, policies, and processes. Every process gives us the output as products, services or sometimes both. These outputs may be tangible or intangible in nature. System controls and maintains the environment required for the required product or service manufacturing [1]. Every product/service has a life cycle called the Product Life Cycle. Similarly, the education system. To enhance the product or system for the next generation, compete in the future globalized market, for better innovations it is the need of the hour to improve our Education System. However, having said that, Digital India is not the Brahmastra for upgrading the Education System. It should be used as an added tool along with the basic learning tools and technologies [2].

\section{DIGITALIZATION EDUCATION :}

Digitalization education is a campaign launched by the government of India to work towards a new approach and to ensure education services are made available to the student electronically by improved online infrastructure by increasing use of the internet or by making education digitally empowered through technology

\section{OBJECTIVES OF THE STUDY :}

(1) To understand and create awareness about the positive and negative impact of Digital India on the education system.

(2) To create awareness about digital technologies in education.

(3) To educate people about digital India.

(4) To know the benefits of Digital technologies in education.

\section{RESEARCH METHODOLOGY:}

This paper is mainly based on both primary as well as secondary data. Primary data is mainly collected from the educational sector mainly from lectures and students about how much they like digital technologies by collecting information through questionnaires. The secondary data is collected from websites related to digital technologies, journals, newspapers, etc. And data are related to Bhatkal taluq.

\section{IMPACT OF DIGITAL INDIA ON EDUCATION SYSTEM :}

There are many impacts of Digital India on the education system, but I will list only important ones.

5.1 Positive Impacts:

1. Great accessibility to information 
2. Develops Inquiry-based learning

3. Develops Problem based learning

4. Develops Project-based learning

5. Great exposure

6. Reduces the cultural gap and removes the boundary

5. 2 Negative Impacts:

1. Information Authenticity - Getting confused with the right and wrong information due to information authenticity [3].

2. Copyrights issue - Unknowingly one can be culprit, just by copy and paste.

3. Irrelevant advertisements will derail your info hunt.

4. Data security - a Root cause of the next world war is not because of land, water, power or any other greediness. It's just because of data infiltration.

5. The single point of failure rate is very high as we depend too much on Digital technologies.

\section{ADVANTAGES OF DIGITAL INDIA ON EDUCATION SYSTEM :}

There are many advantages of Digital India on the education system in Bhatkal taluq, but I will list only important ones.

6.1. Scalable: Digital India helps us to build and communicate new policies, training, ideas and concepts in a quick way. Digital India is nimble whether for entertainment or formal education [3-4].

6.2. Capacity and Consistency: Using Digital India enables educators to achieve a broad degree of coverage for their target audience, and ensures clear delivery of the message. This allows all learners to undergo the same instruction [5].

6.3. High Learning Retention: Blended approaches to learning result in a higher retention of information. It also helps to refresh and update your coursework whenever needed.

6.4. Time and Money Savings: This one is well known and is a staple of any well-functioning Digital India program. Digital India is reducing time off the job, removing the need for travel and removing the need for classroom-based training.

6.5. Activity and performance measurement: If you use a learning management system to deliver your Digital India, then monitoring the progress of learners is a piece of cake, and reporting on this operation is as simple as that.

6.6. Reduction of carbon footprint: The need to print out paper-based tests is minimized by leveraging Digital India for online testing and quizzing, in reality it is practically eliminated altogether [6].

6.7. Flexible: You can offer workers and students the freedom to learn at their own convenience, and at a pace that is right for them, using Digital India. Personnel can be trained as anyone receiving onsite training in remote locations and in a consistent fashion.

\section{DIGITAL TECHNOLOGIES ON EDUCATION SYSTEM :}

7.1 Visual presenter: visual presenter is also called a digital camera. Visual presenter is also one of the parts of digital technologies. It is a teaching tool that allows student and teacher to show and share their view of lots of information to the whole class [7].

7.2 Video projector/interactive video projector: a video projector is a projector that receives the video signals and shows the particular image on the screen of the projector by using the lens system. It projects the image through the video projector by using a very high bright light. This digital technology is used for many applications such as classroom training, conference presentation, concerts, etc.

7.3 Tablet: the original name of the tablet is Tablet computer the short name of this is Tablet. It is very thin and also flat mobile display tablet is totally taken with a sensor including a digital camera accelerometer and microphone. By using the tablet with the internet connection, we can learn any difficult subject also easily.

7.4 Computer: In the modern generation, the computer becomes a part of our life. It also becomes a very important tool in the education system. The educators today not ready to accept technology as their work partner. They feel shy to accept technology. But it is very useful to the educator to share their views about a specific subject the knowledge received through this will be long-lasting in the minds of the learners or viewers [8]. 


\section{International Journal of Case Studies in Business, IT, and Education SRINIVAS (IJCSBE), ISSN: 2581-6942, Vol. 4, No. 2, August 2020.

7.5 Providing teachers and principle with laptops: laptops and desktop now become an important part of education. By providing a laptop to the teachers when the teaching becomes very easy. They used their laptops by connecting to the smartboard to teach their students. Teachers can save their knowledge and their views about the particular subjects into the Laptop [9-11].

7.6 Satellite connected classroom: Satellite connected classrooms means the classroom computer is connected with the satellite, through the satellite connection by searching any particular topic that will appear on the computer screen

By using satellite connection in the education system, we can learn each and everything about the subject easily searched topic about a particular subject is directly displayed on the screen from the internet through satellite connection.

(1) Ensuring schools have a high-quality infrastructure with the WIFI

campus: Must have a robust technological infrastructure which extends wireless high speed. With high-speed internet connectivity, the entire campus is Wi-Fi enabled to allow students to access internet no matter where they are. Wi-Fi coverage is not only limited to classrooms but applies to all areas including library, auditorium, cafeteria, and hostels as well. The students and teachers will be using personal devices to access the school's Wi-Fi network [12].

(2) Developing digital resources for schools such as e-books:-

E-Book is easy to bring. It's better to carry a handheld device that supports eBooks, instead of dragging a bag full of books. Most students these days always carry a mobile-based device. It could be a smartphone, a tablet, a laptop, etc. The portability of an eBook allows students to refer to their notes and course materials whenever they wish to. Instead of bringing several books, the students will now have everything in one place.

\section{DIGITAL TOOLS USED IN BHATKAL TALUQ :}

\subsection{Smart class}

The concept is straight forward. Within the school, a server is set up filled with digital instruction and testing materials mapped to school curriculum classrooms are wired to the server and are fitted with a state-of-the-art digital teaching system (DTS) [13-15] consisting of a highly flexible and interactive screen and sophisticated projection system. In their classroom teachers navigate digital material. Teachers access the digital contents in their classroom sessions and explain the concept with the help of an animation, graphics, videos, etc.

\subsection{Powerpoint:}

Powerpoint is one of the important slide presentation software, nowadays it is a very useful tool in the education system. Through the slide presentation, the learning concept becomes easy, especially in large classes [16-18].

\subsection{Educomp}

In the education sector, there is a major innovation after 2003 that is Educomp. It was a paradigm shift that prior to bringing technology into classroom did what no one had thought of. It inspired teachers with good work mapped to digital curriculum modules that could project to elucidate and clarify concepts right within the classroom.

\subsection{TATA smart class}

TATA Smart class started in 1990 in an interactive system targeting schools in Bhatkal taluq through innovative, interactive educational programs that address the learning exceptional students as well as average students [19-20].

\section{FINDINGSOFDIGITAL EDUCATION :}

Table 1 : Response regarding digital education in Bhatkal taluk

\begin{tabular}{|l|l|l|}
\hline \multicolumn{1}{|c|}{ Questions } & Offender reaction \\
\hline & Yes & No \\
\hline 1)Do you want to develop in digital technologies & $65 \%$ & $35 \%$ \\
\hline 2)Are you aware of digital technologies & $85 \%$ & $15 \%$ \\
\hline 3)Are you connected with the digital technologies & $72 \%$ & $28 \%$ \\
\hline
\end{tabular}




\section{International Journal of Case Studies in Business, IT, and Education SRINIVAS (IJCSBE), ISSN: 2581-6942, Vol. 4, No. 2, August 2020.

4)Are you agree with this technology will help in the education system

$95 \%$

$5 \%$

The above table shows that most of the students and teachers are using digital technologies and their response to digital technologies is positive. From this study, I can realize that in future digital technologies becoming one of the main parts of the education system in Bhatkal taluk

- $65 \%$ of students and teachers want to develop the digital technology in Bhatkal and 35\% of they do not want to develop the digital technologies

- $85 \%$ of students and teachers are aware of digital technology

- Students and teachers are aware agreed with technology is $95 \%$

- Certain students and teachers are not ready to adopt digital technology

10. SUGGESTION :

(1) Digital India should be implemented along with the traditional learning methodologies in the education system.

(2) Writing is one of the best and natural powerful creativity tools and it should be preserved from the storm of Digital India.

(3) With the lightening of the speed of market competition, Digital India is need of the hour with extra precautions [21-23].

\section{CONCLUSION :}

It is not the strongest of the living species, nor the brightest, but the one that is most open to change. Since changes are happening anyway, the best thing is to know more about them, so we can lay hold of them and turn them in the direction of our wishes [23]. Conditions and events are neither to be fled from nor passively acquiesced in they are to be utilized and directed.

\section{REFERENCES :}

[1] Kolb, D. A. And Fry, R. (1975). Toward an Applied Theory of Experiential Learning. In Theories of Group Process, Edited by Cooper, 1(2), 33-58.

[2] Bronfenbrenner, U. (1994). Ecological Models of Human Development. International Encyclopedia of Education, 2(3), 1643-1647.

[3] Mason, R., and Weller, M. (2000). Factors affecting students' satisfaction on a web course. Australian Journal of Educational Technology, 16(2), 173-200.

[4] Rajesh, M. (2003). A Study of the problems associated with ICT adaptability in Developing Countries in the context of Distance Education. Turkish Online Journal of Distance Education, 4(2) $133-142$.

[5] Venkatesh, V., Morris, M. G., Davis, G. B., \& Davis, F. D. (2003). User Acceptance of Information Technology: Toward A Unified View. MIS Quarterly, 27(3), 425-478.

[6] Burn, J., and Thongprasert, N. (2005). A culture-based model for strategic implementation of virtual education delivery. International Journal of Education and Development using Information and Communication Technology, 1(1), 32-52.

[7] Jiang, M., and Ting, E. (2005). A Study of Factors Influencing Students' Perceived Learning in a Web- Based Course Environment. International Journal of Educational Telecommunications, 6(4), 317-338.

[8] Schilling K, Wiecha J, Polineni D, Khalil S. (2006). An Interactive Web-Based Curriculum on Evidence-Based Medicine: Design and Effectiveness. Fam Med. Warnecke E, Pearson, 38(2), 126-32.

[9] Saunders, M., Lewis, P., \& Thornhill, A. (2007). Research Methods for Business Students, Fourth Ed. Pearson Education Limited, Harlow, England, 3(4), 624-672. 
[10] Jadhav, Vaibhav. (2011). ICT and Teacher Education. International Educational E-Journal,1(1), $64-69$.

[11] Bosamia, Mansi Prakashbhai. (2013). Positive and Negative Impacts of ICT in our Everyday Life, accessed from https://www.researchgate.net/publication/325570282 2.

[12] Butler, D., Leahy, M., Shiel, G., \& Cosgrove, J. (2013). A Consultative Paper Building towards Learning Society: A National Digital Strategy for Schools. Dublin: Educational Research Centre, 5(1), 22-39.

[13] Chen, L. M., and Cheng, Y. Y. (2013). Prevalence of School Bullying among Secondary Students in Taiwan: Measurements with and without a Specific Definition of Bullying. Journal of School Psychology International, 1(34), 707-720.

[14] Kamble, Avishkar D. (2013). Digital Classroom: The Future of the Current Generation. International Journal of Education and Psychological Research, 2(2), 41 - 45.

[15] Nazarlou, Mortaza Mokhtari (2013). Research on Negative Effect on E-Learning. International Journal of Mobile Network Communications \& Telematics, 3(2), 11 - 16.

[16] Simuforosa, Magwa (2013). The Impact of Modern Technology on the Educational Attainment of Adolescents. International Journal of Education and Research,1(9), 1 - 8.

[17] Byker, Erik Jon (2014). ICT in India's Elementary Schools: The Vision and Realities. The International Education Journal: Comparative Perspectives, 13(2), 27 - 40.

[18] Jani, J., \& Tere, G. (2015). Digital India: A need of Hours. International journal of advanced research in computer science and software engineering, 5(8), 317-319.

[19] Nigam, Anushree. Srivastava, Jyoti. Lakshmi, Tanushree. Vaish, Anurika (2015). Digitizing Education: A Cost Benefit Analysis. Asian Journal of Information Science and Technology, 5(1), 1 5.

[20] Himakshi Goswami (2016). Opportunities and challenges of digital India programme. International Education \& Research Journal, 2(11), 78-79.

[21] Jha, Nivedita., Shenoy, Veena (2016). Digitization of Indian Education Process: A Hope or Hype. IOSR Journal of Business and Management, 18(10), 131 - 139.

[22] Shikha Dua1, Seemawadhawan, Sweety Gupta (2016). Issues, trends \& challenges of digital education: an empowering innovative classroom model for learning. International Journal of Science Technology and Management, 5(5), 142-149.

[23] Jayesh M. Patel (2017). Web based tools of technology in future teaching learning strategies. International Education \& Research Journal [IERJ], 3(2), 5-6. 